\title{
SOSIALISASI VARIASI PRODUK UKM DAN PENGELOLAAN KEUANGAN BUMDESA DI ERA NEW NORMAL DI DESA MANJALLING KABUPATEN BULUKUMBA
}

\author{
${ }^{1}$ Orfyanny S.Themba, ${ }^{2}$ Asbi Amin dan ${ }^{3}$ Indrawan Azis \\ ${ }^{1}$ STIEM Bongaya Makassar, orfyanny.sthemba@stiem-bongaya.ac.id \\ ${ }^{2}$ STIEM Bongaya Makassar, asbi.amin@stiem-bongaya.ac.id \\ ${ }_{3}^{3}$ STIE Nobel Indonesia Makassar, indrawan@stienobel-indonesia.ac.id
}

\section{Article history}

Received: 29 Agustus 2021

Revised: 01 Oktober 2021

Accepted: 04 Oktober 2021

\section{Corresponding}

Author:

Asbi Amin

STIEM Bongaya Makassar,

Indonesia

Email: asbi.amin@stiem-

bongaya.ac.id

\section{PENDAHULUAN}

Desa Manjalling adalah Desa yang terletak di Kecamatan Ujung Loe yang terletak di bagian timur Kabupaten Bulukumba dengan jarak kurang

\begin{abstract}
Abstrak
Tujuan dan target dari BUMDes dapat dicapai jika dikelola dengan benar dan profesional karena dalam esensi BUMDes adalah hadir sebagai solusi bagi masyarakat dalam mengembangkan usaha kreatif dan UKM di desa. Atas dasar permasalahan yang terjadi pada mitra maka program PKM ini perlu dilakukan dengan memberikan sosialisasi tentang berbagai peluang usaha yang dapat dilakukan UKM di Era New Normal.dan tata Kelola keuangan BUMDes yang baik melalui aplikasi akuntansi sederhana sesuai dengan akuntansi yang berlaku umum. Metode yang digunakan adalah diskusi dan ceramah. Kegiatan pengabdian yang dilakukan Tim PKM ini dengan metode ceramah dan diskusi telah mampu memberikan motivasi bagi masyarakat di Desa Manjalling untuk melakukan variasi produk pada UKMnya terlebih lagi atas dukungan dari Kepala Desa Manjalling, para pelaku UKM, tokoh masayarakat dan pengurus BUMdes yang dijadikan sebagai sasaran kegiatan pengabdian pada Masyarakat. Kegiatan Pengabdian pada masyarakat ini juga dapat membantu bagi pengurus BUMdes mengetahui dan memahami tata kelola keuangan BUMDes yang baik melalui aplikasi akuntansi sederhana sesuai dengan akuntansi yang berlaku umum.
\end{abstract}

Kata kunci — Inovasi Produk, BUMDes.

\section{Abstract}

The goals and targets of BUMDes can be achieved if managed properly and professionally because in essence BUMDes is present as a solution for the community in developing creative businesses and SMEs in the village. Based on the problems that occur with partners, this PKM program needs to be carried out by providing socialization about various business opportunities that can be carried out by SMEs in the New Normal Era. And good BUMDes financial governance through simple accounting applications in accordance with generally accepted accounting. The method used is discussion and lecture. The service activities carried out by the PKM Team with the lecture and discussion methods have been able to provide motivation for the people in Manjalling Village to make product variations for their SMEs, especially with the support from the Manjalling Village Head, SME actors, community leaders and BUMdes management who are used as the target of the activity. community service. This community service activity can also help BUMdes management know and understand good BUMDes financial governance through simple accounting applications in accordance with generally accepted accounting.

Keyword-Product Innovation, BUMDes. 
manjalling terdiri atas tiga Dusun yaitu Dusun Kailie, Palattae dan Parunge dengan jumlah penduduk sebanyak 2.729 jiwa dengan jumlah KK 666 keluarga. Penduduk laki-laki dan perempuan Desa manjalling penduduk laki-laki sebesar 1.254 jiwa dan perempuan sebesar 1.475 jiwa.

Desa Manjalling merupakan daerah hasil pemekaran dari desa Garanta, beberapa potensi yang terdapat pada desa manjalling berupa bidang pertanian seperti: padi, kacang hijau, kelapa, pada bidang perikanan: budidaya empang yang menghasilkan ikan Bandeng, Kepiting dan Udang. dan serta usaha-usaha kecil lainnya seperti pertokoan dengan usaha meubel dan usaha kuliner disepanjang jalan poros pantai

Sejak pemerintah mengumumkan wabah Covid-19 masuk di Indonesia pada Maret 2020, penyebaran virus ini kini menjadi masalah Kesehatan bagi rakyat Indonesia, karenanya pemerintah mengeluarkan kebijakan sekolah, beberapa Aparatur Sipil Negara (ASN) dan pegawai Badan Umum Milik Negara (BUMN) dapat bekerja secara online dari rumah dalam rangka mengatasi penyebaran Covid-19.

Disamping itu, kebijakan Provinsi, Kabupaten atau Kota melakukan isolasi daerah yang berdampak besar pada perekonomian. Desa Manjalling sebagai salah satu desa yang merasakan lambatnya perekonomian sejak adanya Covid-19.

Melihat perkembangan ekonomi yang melambat, maka pemerintah mengeluarkan kebijakan new normal dengan protokol pencegahan Covid-19 baik di perkotaan maupun di pedesaan dimana ASN kembali berkantor, beberapa tempat umum di daerah-daerah kembali dibuka untuk menghindari dampak ekonomi yang nantinya akan menyebabkan krisis jangka Panjang.

Kementerian Desa Pembangunan Daerah Tertinggal dan Transmigrasi (Kemendes PDTT) menyatakan bahwa desa menjadi pilar penting pembangunan nasional, karenaya potensi yang dimiliki desa dan Badan Usaha Milik Desa (BUMDes) akan dikelola secara maksimal di masa newnormal dengan membuka Kembali desa wisata. Hal itu diyakini dapat menahan tekanan dampak Covid-19 guna memulihkan ekonomi desa (https://pasardana.id/news, Juli 2020).

Dengan BUMDes diharapkan akan menarik masyarakat untuk merangsang dan memulai perdagangan sehingga akan perlahan meningkatkan ekonomi dan mencegah kemiskinan (Wojongan, 2021). Kegiatankegiatan usaha ekonomi masyarakat ditampung di dalam BUMDes sebagai suatu kelembagaan yang dikelolah secara profesional, sehingga usaha masyarakat lebih efektif dan produktif (Hidayah et al., 2019).

Prospek yang dapat diandalkan pada potensi desa dalam mengembangkan ekonomi pedesaan melalui lembaga pemberdayaan, yaitu Badan Usaha Milik Desa (BUMDes) dapat dikelola secara profesional karena potensi alam dapat dipercaya, seperti pertanian, perkebunan, kelautan dan bisnis mikro. Desa dapat mengelola produk dari sumber daya sendiri yang dijadikan produk unggulan, sebagaimana tertuang dalam Peraturan Menteri Desa PDTT Republik Indonesia (Rahayu \& Febrina, 2021).

BUMDes bertujuan untuk meningkatkan perekonomian desa, mengoptimalkan aset desa agar bermanfaat untuk kesejahteraan desa, meningkatkan usaha masyarakat dalam pengelolaan potensi ekonomi desa (Fitriska, 2017). Dengan BUMDes juga dapat mengembangkan rencana kerja sama usaha antar desa dan/atau dengan pihak ketiga, menciptakan peluang dan jaringan pasar yang mendukung kebutuhan layanan umum warga, membuka lapangan kerja, meningkatkan kesejahteraan masyarakat melalui perbaikan pelayanan umum, pertumbuhan dan pemerataan ekonomi desa dan meningkatkan pendapatan masyarakat desa dan pendapatan asli desa (Ihsan \& Setiyono, 2018). Pengelolaan BUMDesa diharapkan dapat dilakukan secara professional sehingga dapat menjadi BUMDesa yang mandiri yang pada akhirnya akan mampu menjadi pendukung kesejahteraan masyarakat dan menjadi sumber penerimaan anggaran desa pada waktu yang bersamaan keberadaan BUMDesa juga tidak hanya berorientasi pada keuntungan dan laba bisnis semata namun lebih dari itu BUMDesa dapat menjadi pendukung kesejahteraan sosial serta manfaat-manfaat non ekonomi lainnya yang dapat dirasakan oleh Masyarakat Desa (Hidayat et al., n.d.)

Memanfaatkan peluang, seorang wirausaha setidaknya telah memiliki sikap kreatif dan inovatif (Hidayat \& Citra, 2020). Dan untuk menerapkan ide kreatif dan inovatif dibutuhkan usaha yang sungguh-sungguh, tekun, konsisten, dan penuh motivasi yang tinggi (Suryati \& Sadjiarto, 2018). Sehingga para pengusaha bekerja keras dengan segala kemampuannya terhadap harapan usaha yang dijalankan dapat 
bertahan ditengah perubahan situasi dan kondisi yang berubah secara cepat (Ibrahim et al., 2021).

Tabel 1. Perkembangan Alokasi Dana Desa

\begin{tabular}{|c|c|c|}
\hline Tahun & $\begin{array}{c}\text { Alokasi } \\
\text { (dalam Triliun } \\
\text { Rupiah) }\end{array}$ & $\begin{array}{c}\text { Rata-rata } \\
\text { perdesa dalam } \\
\text { Juta Rupiah }\end{array}$ \\
\hline 2016 & 46,98 & 628 \\
\hline 2017 & 60 & 800 \\
\hline 2018 & 60 & 800 \\
\hline 2019 & 70 & 933 \\
\hline 2020 & 72 & 960 \\
\hline
\end{tabular}

Sumber : Direktorat Jenderal Perimbangan Keuangan, 2020.

Jumlah dana yang dialokasikan ke desa dalam 5 tahun terakhir harus dinilai berdasarkan pelaksanaan dana desa. Prioritas penggunaan dana desa adalah untuk membiayai kegiatan pembangunan desa dan pemberdayaan masyarakat desa (Kogoya et al., 2020). Untuk itu, perlu dilakukan evaluasi apakah dana desa sudah efektif diterapkan dan pelaksanaannya telah mencapai tujuan yang diharapkan (Amin \& Astuti, 2021).

Tujuan dan target dari BUMDes dapat dicapai jika dikelola dengan benar dan profesional karena dalam esensi BUMDes adalah hadir sebagai solusi bagi masyarakat dalam mengembangkan usaha kreatif dan UKM di desa (Senjani, 2019). Pengembangan BUMDes harus dilakukan agar BUMDes yang telah hadir dapat berjalan sesuai dengan perannya. BUMDes juga diharapkan mampu merangsang dan menggerakkan roda perekonomian desa (Sinaga, 2019).

Hasil penelitian (Pristiani \& Suratman, 2018) BUMDes adalah inovasi pembangunan desa yang bertujuan untuk menguatkan ekonomi masyarakat desa, namun keberhasilanya belum terlihat cukup baik di banyak desa. Kegiatankegiatan usaha ekonomi masyarakat ditampung di dalam BUMDes sebagai suatu kelembagaan yang dikelolah secara profesional, sehingga usaha masyarakat lebih efektif dan produktif (Farrah et al., 2021).

(Gayo et al., 2020) dan (Hailudin, 2021) mengemukakan bahwa BUMDes berperan dan berkontribusi kepada perekonomian masyarakat walaupun belum dikatakan terbesar karena masih ada ketimpangan kesejahteraan di antara komunitas, masih terdapat kendala kekurangan dana, pengetahuan masyarakat tentang pengelolaan BUMDes masih terbatas.

Berdasarkan survei pendahuluan yang dilakukan oleh Tim Pengabdian Masyarakat ini ditemukan masalah di Desa Manjalling sebagai berikut:

a. Masyarakat desa Manjalling tidak mengetahui variasi produk pada bidang pertanian dan perkebunan apa yang bisa dikembangkan UKM di era new normal.

b. Masyarakat desa Manjalling belum memahami tentang peran BUMdes dalam meningkatkan perekonomian desa.

c. Aparatur desa belum memahami pengelolaan keuangan BUMDes yang baik. Sehingga system pengelolaan keuangan dan manajemen belum ada untuk dapat diterapkan di BUMDes.

Atas dasar permasalahan yang terjadi pada mitra maka program PKM ini perlu dilakukan dengan memberikan sosialisasi tentang berbagai peluang usaha yang dapat dilakukan UKM di Era New Normal.dan tata Kelola keuangan BUMDes yang baik melalui aplikasi akuntansi sederhana sesuai dengan akuntansi yang berlaku umum.

\section{METODE}

Metode yang digunakan dalam kegiatan pengabdian pada Masyarakat ini adalah :

1. Ceramah

Metode ceramah di gunakan untuk menjelaskan secara singkat tentang BUMdes melalui kegiatan Seminar sosialisasi BUMdes dan Pengembangan UKM Bagi Masyarakat Desa Manjalling. Dalam metode ceramah ini dilakukan selama 2 jam terdiri 1 jam .materi yang dipaparkan tentang pengertian BUMdes, tujuan pembentukan BUMdes, manfaat BUMdes bagi perekonomian dan 1 jam memaparkan materi bagaimana masyarakat lebih kreatif dalam pemanfaatan dan pengembangan potensi yang dimiliki desanya untuk menghasilkan suatu produk.

2. Diskusi

Diskusi dilakukan untuk menampung semua pertanyaan peserta pada selama kegiatan sosialisasi dan membantu mencarikan solusinya, dengan demikian kegiatan ini akan efektif karena adanya berbagai macam masukan dan informasi masalah yang dihadapi dilapangan yang terkait dengan masalah yang selama ini dihadapi oleh masyarakat dalam menjalankan usahanya dan pengelolaan BUMdes yang belum efektif selama 2 jam. 
Adapun bahan sosialisasi serta diskusi yang diajukan mengarah pada pokok analisis permasalahan yang akan diteliti yaitu tentang berbagai peluang usaha di masa krisis dan startegi pemasaran untuk mengembangkan bisnis di era New Normal sepanjang pandemi Covid 19 dan pasca pandemi.

Peserta diberikan pengetahuan dan pemahaman tentang era New Normal dan kebijakan-kebijakan di dalamnya, strategi mempertahankan bisnis di masa krisis pandemi, startegi pemasaran di era New Normal dan motivasi untuk terus mengembangkan UMKM dengan ekonomi kreatif serta pemasaran dengan memanfaatkan media sosial agar dapat terus bertahan di era New Normal sepanjang Covid 19 sehingga roda perekonomian terus berjalan. Peserta juga dapat mengenal lebih jauh tentang berbagai peluang usaha UMKM di era krisis. Dalam pelaksaaan PKM ini juga melibatkan sejumlah mahasiswa STIE Nobel Indonesia yang berpartisipasi untuk menyalurkan informasi sosialisasi kepada masyarakat di wilayah PKM.

Adapun langkah-langkah kegiatan dalam pengabdian pada masyarakat ini adalah melalui tahapan-tahapan sebagai berikut :

1. Pemetaan masalah dan potensi

a. Lokasi sumber daya dan batas-batas wilayah.

b. Jenis usaha UKM yang ada di lokasi

1. Masalah yang dihadapi oleh UKM.

2. Potensi yang dimiliki dalam mengatasi masalah yang dihadapi oleh UKM.

3. Perubahan-perubahan sumber daya yang terjadi.

2. Identifikasi calon peserta pelatihan

a. Observasi

b. Social Area Survey

3. Penentuan Jadwal Kegiatan

4. Persiapan Perlengkapan Kegiatan

5. Pelaksanaan Kegiatan

\section{HASIL DAN PEMBAHASAN}

Sosialisasi kegiatan inovasi peluang bisnis untuk UKM dan pengelolaan keuangan BUMDes di era Normal di Desa Majjaling Kabupaten Bulukumba telah diadakan pada 15 september 2020 hingga 30 september 2020 yang berlangsung di aula desa setempat. Dalam sosialisasi itu penulis segera menjadi guestrium. Dalam sosialisasi juga dibantu oleh Sejumlah mahasiswa STIE Nobel Indonesia Makassar.

Target kegiatan sosialisasi ini adalah UKM dan komunitas yang berkepentingan di Desa
Majjaling Kabupaten Bulukumba. Penentuan tujuan ini adalah upaya untuk menyampaikan pengetahuan dan pemahaman kepada peserta terntang berbagai peluang bisnis untuk UKM dan pengelolaan keuangan BUMDes di era new normal.

Kegiatan Pengabdian Masyarakat ini telah dilaksanakan oleh tim pelaksana Pengabdian Kepada Masyarakat ini, yaitu : Orfyanny S. Themba SE., M.Si selaku penulis dan pembicara yang menyampaikan materi menggali potensi desa untuk inovasi peluang usaha di masa new normal dan strategi pemasaran yang efektif di era new normal. Pemateri berikutnya Asbi Amin, SE., M.Ak yang menyampaikan materi terkait tujuan BUMDes dan dasar pengelolaan dana di desa. Pemateri ketiga Indrawan Azis, SE., M.Ak memaparkan materi pelaporan dan pertanggungjawaban.

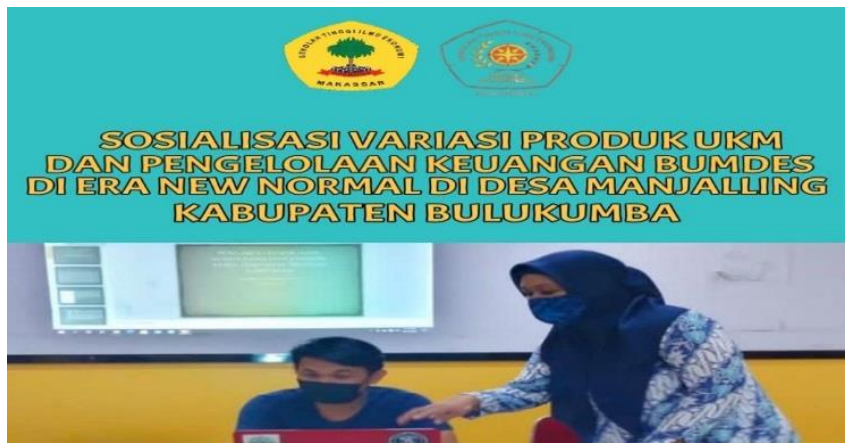

Gambar 1. Salah satu Narasumber Saat Memaparkan Materi

Segala kegiatan dilaksanakan dengan mengikuti standar protokol Covid-19 dimana dalam penyelenggarannya telah di lakukan pengawasan dan inspeksi oleh Satgas Covid-19 setempat. Sikap antusias Masyarakat Desa Manjalling dapat juga dilihat dari dalam jumlah peserta seminar sosialisasi yang melebihi target dan respon balik dari peserta dengan banyaknya pertanyaan seputar bagaimana pengembangan produk yang akan dipasarakan agar dapat memiliki nilai tambah dan unggul dipasaran, apa peranan BUMdes bagi masyarakt desa dan bagaimana agar BUMdes yang ada sekarang dapat aktif kembali.

Pelaku UKM yang sempat hadir, mulai terbuka pola pikirmya untuk mengembangkan produk yang sudah ada menjadi produk yang lebih kreatif dan memiliki nilai jual yang tinggi. Melalui sosialisai BUMdes ini para pelaku UKM sudah memiliki tempat atau wadah untuk menampung hasil produksi dan membantu dalam penambahan modal usaha. 


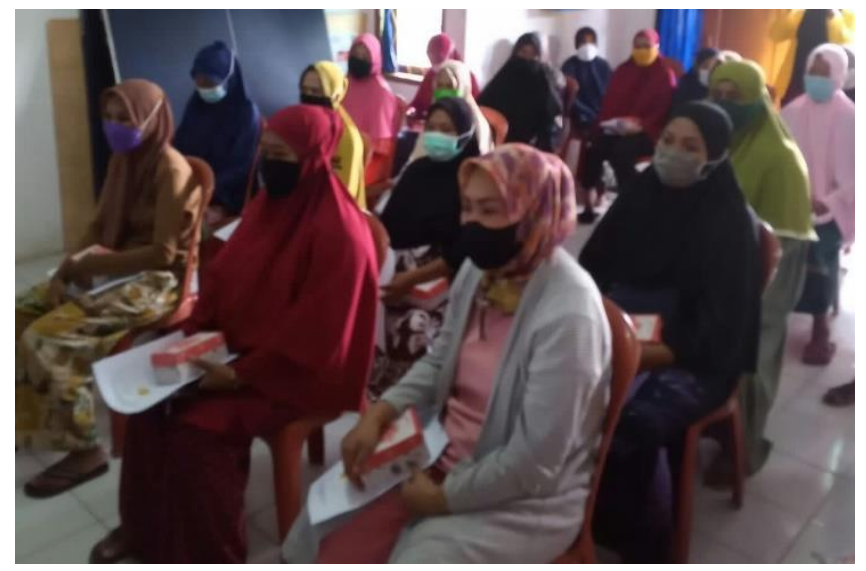

Gambar 2. Suasana antusias peserta Sosialisasi

Hasil pelaksanaan kegiatan Pengabdian

Pada Masyarakat secara keseluruhan dapat dilihat dari beberapa komponen berikut ini :

1. Ketercapaian Target Jumlah Peserta

Target peserta pelatihan atau sasaran kegiatan adalah masyarakat Desa Manajalling yang terdiri dari Tokoh masyarakat, pengurus BUMdes dan pelaku UKM. .Walaupun pelaku UKM dan pengurus BUMdes yang hadir belum maksimal tapi jumlah peserta melebihi dari target yang telah di tetapkan, ini membuktikan bahwa antuasias para masyarakat desa sangat besar dalam mengikuti kegiatan seminar sosiliasasi BUMdes.

2. Ketercapaian Tujuan

Ketercapaian tujuan dari kegiatan pengabdian pada masyarakat ini masyarakat akan pentingnya peranan BUMdes dalam peningkatan perekonomian desa dengan membangun potensi desa menjadi produk yang unggul. Seminar Sosialisasi BUMdes ini menambah pemahaman bagi masyarakat tentang BUMdes dan apa peranannya bagi masayarakt desa.

Dalam seminar sosialisai BUMdes ini para masyarakat utamanya pelaku UKM diberikan pengetahuan akan pentingnya semangat kewirausahaan serta diberikan tipstips untuk mencapai kesuksesan terutama dalam hal kewirausahaan. Serta para masyarakat desa diberikan contoh-contoh sosok seorang wirausaha yang sukses, untuk memberikan suatu motivasi kepada masyarakat agar memiliki jiwa kewirausahaan. Serta menggali sumbersumber daya yang ada di Desa Manjalling kemudian mengidentifikasi usaha yang cocok untuk dijadikan kegiatan usaha.

Terkhusus pengurus BUMdes yang selama ini vakum setelah mengikuti seminar sosialisai ini mereka mulai membentuk kembali pengurus baru BUMdes yang diharapkan kedepannya akan menjadi BUMdes yang membantu perekonomian masyarakat dan menjadi BUMdes terbaik di kecamatan ujung loe.

3. Ketercapaian Target Materi yang Direncanakan.

Apabila kita melihat materi yang berikan dan bimbingan langsung dilapangan sudah mencapai target yang telah di tetapkan, dimana pemilihan materi ditetapkan setelah melakukan survei sebelumnya tentang apa yang dibutuhkan oleh masayarakat yang ada di Manjalling, dimana kehadiran kami untuk melakukan kegiatan pengabdian pada masyarakat ini tujuan adalah agar Meningkatkan kesadaran masyarakat akan pentingnya peranan BUMdes dalam peningkatan perekonomian desa dan membantu masyarakat dalam mengatasi kemiskinan dan pengangguran.

4. Kemampuan Peserta dalam Mengikuti Setiap Proses Kegiatan

Kemampuan peserta yang menjadi sasaran dalam kegiatan pengabdian pada masyarakat ini dinilai baik, dimana antusiasme masyarakat dalam mengikuti setiap kegiatan yang telah di rancang sangat baik dan dukungan dari pemerintah setempat dalam hal ini kepala Desa Manjalling yang memberikan dukungan penuh selama kegiatan ini berlangsung mereka tidak segan untuk bertanya kepada fasilitator apabila ada hal-hal yang tidak di mengerti.

\section{KESIMPULAN DAN SARAN}

Kegiatan pengabdian yang dilakukan Tim PKM ini dengan metode ceramah dan diskusi telah mampu memberikan motivasi bagi masyarakat di Desa Manjalling untuk melakukan variasi produk pada UKMnya terlebih lagi atas dukungan dari Kepala Desa Manjalling, para pelaku UKM, tokoh masayarakat dan pengurus BUMdes yang dijadikan sebagai sasaran kegiatan pengabdian pada Masyarakat. Kegiatan Pengabdian pada masyarakat ini juga dapat membantu bagi pengurus BUMdes mengetahui dan memahami tata kelola keuangan BUMDes yang baik melalui aplikasi akuntansi sederhana sesuai dengan akuntansi yang berlaku umum.

Dari kesimpulan tentang kegiatan pengabdian pada masyarakat diatas, maka ada beberapa saran yang perlu untuk diperhatikan 
dalam melakukan kegiatan pengabdian pada masyarakat di masa yang akan datang antara lain:

1. Agar pelaksanaan kegiatan pengabdian dapat mencapai sasaran yang diharapkan maka untuk kedepannya di butuhkan waktu yang lebih lama, dan pendampingan yang berkesinambungan dan perlu adanya kerjasama antara pihak Perguruan Tinggi dan Pemerintah.

2. Perlu pendampingan yang dilakukan oleh dinas perindustrian maupun perdagangan sehingga pelaku usaha dapat mempertahankan dan mengembangkan usahanya serta melakukan pengelolaan keuangan dengan benar.

3. Perlu adanya contoh dalam inovasi produk dengan memanfaatkan sumber daya yang ada di daerah yang bersangkutan sehingga tidak membuat harga produk tidak terlalu mahal dan dapat bersaing dengan produk lain. Produk inovasi ini harus dilakukan oleh dinas yang berkaitan dengan UKM yang menggandeng perguruan tinggi maupun pelaku UKM lain yang telah melaksanakan inovasi produk.

\section{DAFTAR PUSTAKA}

Amin, A., \& Astuti, N. P. (2021). Akuntansi BUMDes di Desa Je'nemadinging Kabupaten Gowa. Jurnal Komunitas: Jurnal Pengabdian Kepada Masyarakat, 3(2), 137142.

Farrah, A. I., Prayitno, G., Arizkha, Y. F., Nur, Z. A., \& Alfisyah, B. D. (2021). STRATEGI TRANSFORMASI DESA JIMBARAN MENUJU DESA MANDIRI MELALUI PENGOLAHAN KOPI DAN OPTIMALISASI BUMDES. GEOGRAPHY: Jurnal Kajian, Penelitian Dan Pengembangan Pendidikan, 9(1), 32-44.

Fitriska, K. (2017). Strategi Pengembangan Badan Usaha Milik Desa Dalam Meningkatkan Kesejahteraan Masyarakat di Desa Lancang Kuning Kecamatan Bintan Utara. Jurnal Ilmu Administrasi Negara (JUAN), 5(2), 29-34.

Gayo, S. B., Erlina, E., \& Rujiman, R. (2020). Peranan Badan Usaha Milik Desa Dalam Meningkatkan Perekonomian Masyarkat Perdesaan. Media Komunikasi Geografi, 21(2), 202-209.

Hailudin, H. (2021). Peranan Badan Usaha Milik Desa (BUMDES) Dalam Pemberdayaan Ekonomi Masyarakat Desa Labuhan Haji
Lombok Timur. Elastisitas-Jurnal Ekonomi Pembangunan, 3(1), 1-9.

Hidayah, U., Mulatsih, S., \& Purnamadewi, Y. L. (2019). Evaluasi Badan Usaha Milik Desa (BUMDes): Studi kasus BUMDes Harapan Jaya Desa Pagelaran, Kecamatan Ciomas, Kabupaten Bogor. Jurnal Sosial Humaniora Dan Pendidikan, 3(2), 144-153.

Hidayat, M., \& Citra, C. (2020). PENGARUH KOMPETENSI KEWIRAUSAHAAN, ORIENTASI PASAR DAN MOTIVASI BERWIRAUSAHA TERHADAP KINERJA BISNIS WARUNG KOPI DI KOTA MAKASSAR. Jurnal Mirai Management, 5(1), 244-256.

Hidayat, M., Latief, F., \& Asbara, N. W. (n.d.). Revitalisasi BUMDesa Melalui Penelolaan Potensi Lokal Untuk Mewujudkan BUMDesa Yang Sehat Dan Mandiri.

Ibrahim, A. H., La Suhu, B., Suaib, R., Salim, A., \& Noor, N. (2021). STRATEGI PENGEMBANGAN BADAN USAHA MILIK DESA DALAM MENINGKATKAN PEREKONOMIAN MASYARAKAT PERDESAAN (Studi di Desa Were Kecamatan Weda Kabupaten Halmahera Tengah). JURNAL GOVERNMENT OF ARCHIPELAGOJGOA, 2(1), 1-10.

Ihsan, A. N., \& Setiyono, B. (2018). Analisis Pengelolaan Badan Usaha Milik Desa (BUMDes) Gerbang Lentera Sebagai Penggerak Desa Wisata Lerep. Journal of Politic and Government Studies, 7(04), 221230.

Kogoya, F., Partino, P., \& Muhdiarta, U. (2020). Implementasi Kebijakan Alokasi Dana Desa di Distrik Kembu Kabupaten Tolikara Provinsi Papua. Jurnal Kebijakan Publik, 3(3), 127-135.

Pristiani, Y. D., \& Suratman, S. (2018). Badan Usaha Milik Desa Sanankulon Melek Administrasi Dan Melek It Untuk Menumbuhkan Dan Mengembangkan Ekonomi Kreatif Masyarakat Desa Sanankulon Kecamatan Sanankulon Kabupaten Blitar. Jurnal ABDINUS: Jurnal Pengabdian Nusantara, 1(2), 144-151.

Rahayu, S., \& Febrina, R. (2021). PEMBERDAYAAN MASYARAKAT DESA MELALUI BUMDES DI DESA SUGAI NIBUNG. JURNAL TRIAS POLITIKA, 5(1), 49-61.

Senjani, Y. P. (2019). Peran Sistem Manajemen 
Volume 1 Namar 1 Tahun 2021

pada BUMDes dalam Peningkatan Pendapatan Asli Desa. Kumawula: Jurnal Pengabdian Kepada Masyarakat, 2(1), 2340.

Sinaga, M. S. (2019). BANK DESA SEBAGAI INOVASI EKONOMI PEMBANGUNAN BERKELANJUTAN MELALUI STRATEGI KEMITRAAN DAN TATA KELOLA PEMERINTAHAN. Jurnal Ilmiah Akuntansi Dan Finansial Indonesia, 2(2), 41-52.

Suryati, K., \& Sadjiarto, A. (2018). Analisis
Pengembangan Usaha Fanny Cake n'Bakery Salatiga. Ecodunamika, 1(3).

Wojongan, A. V. E. (2021). PENGELOLAAN BADAN USAHA MILIK DESA (BUMDes) DITENGAH PANDEMI COVID 19 (Studi di Desa Wiau Kecamatan Posumaen Kabupaten Minahasa Tenggara). JURNAL POLITICO, 10(4). 